\title{
Small Intestinal Muscular Coat
}

National Cancer Institute

\section{Source}

National Cancer Institute. Small Intestinal Muscular Coat. NCI Thesaurus. Code C33569.

Muscular coat consisting of two layers of smooth muscle - an external, longitudinal, and an internal, circular layer. The long itudinal fibers are thinly scattered over the surface of the small intestine, and are more distinct along its free border. The circular fibers form a thick, uniform layer, and are composed of plain muscle cells of considerable length. The muscular coat is thicker at the upper than at the lower part of the small intestine.

Interstitial cells of Cajal are present in the small intestinal muscular coat. 